ISSN 1810-3030 (Print) 2408-8684 (Online)

Journal of Bangladesh Agricultural University

Journal home page: http://baures.bau.edu.bd/jbau, www.banglajol.info/index.php/JBAU

\title{
Effect of cow dung as organic manure on the growth, leaf biomass yield of Stevia rebaudiana and post harvest soil fertility
}

\author{
M. M. Zaman ${ }^{1}$, T. Chowdhury ${ }^{2}$, K. Nahar ${ }^{3}$ and M. A. H. Chowdhury ${ }^{3}$ \\ ${ }^{1}$ Soil Resources Development Institute, Farmgate, Dhaka, Bangladesh \\ ${ }^{2}$ Department of Agricultural Chemistry, Sher-E-Bangla Agricultural University, Dhaka-1207, Bangladesh \\ ${ }^{3}$ Department of Agricultural Chemistry, Bangladesh Agricultural University, Mymensingh, Bangladesh
}

\begin{tabular}{|c|c|}
\hline ARTICLE INFO & Abstract \\
\hline $\begin{array}{l}\text { Article history: } \\
\text { Received: } 19 \text { October } 2017 \\
\text { Accepted: } 11 \text { November } 2017\end{array}$ & $\begin{array}{l}\text { Organic manures as a source of plant nutrients for cultivation of field crops has received worldwide } \\
\text { attention due to rising costs, rapid nutrient loss and adverse environmental impacts from inorganic } \\
\text { fertilizers. A pot experiment was conducted in the net house of the Department of Agricultural Chemistry, } \\
\text { Bangladesh Agricultural University, Mymensingh to observe the effects of cow dung on growth, vield of }\end{array}$ \\
\hline $\begin{array}{l}\text { Keywords: } \\
\text { Cow dung, Stevia, Leaf yield, } \\
\text { Post-harvest soil }\end{array}$ & $\begin{array}{l}\text { stevia along with post-harvest fertility status of soil. Four treatments of CD viz. } 0,5,7.5 \text { and } 10 \mathrm{tha}^{-1} \text { in } \\
\text { two contrasting soils (acid and non-calcareous) were examined following Completely Randomized Design } \\
\text { (CRD) with three replications. Growth and yield attributes increased significantly with the advancement } \\
\text { of growth period (60 DAP) and increased rate of CD up to } 10 \mathrm{t} \mathrm{ha}^{-1} \text {. An overall performance of non- }\end{array}$ \\
\hline $\begin{array}{l}\text { Correspondence: } \\
\text { M.A.H. Chowdhury } \\
\text { (akhterbau11@ gmail.com ) }\end{array}$ & $\begin{array}{l}275 \% \text { whereas in acid soil it was } 268 \% \text { over control. The acidity of both soils significantly decreased with } \\
\text { the increased rate of CD. All essential plant nutrients viz. total N, available P exchangeable } \mathrm{K}, \mathrm{Ca}, \mathrm{Mg} \text {, } \\
\text { available } \mathrm{S}, \mathrm{Zn}, \mathrm{B} \text { and organic matter content of soil were significantly increased with the increased levels } \\
\text { of CD up to its highest dose (CD @ } 10 \mathrm{tha}^{-1} \text { ) in both soils. Thus from the findings of the present research } \\
\text { work it can be concluded that for getting optimum leaf biomass yield of stevia along with fertility of both } \\
\text { soils CD should be applied @ } 10 \mathrm{tha}^{-1} \text {. }\end{array}$ \\
\hline
\end{tabular}

\section{Introduction}

Stevia, the nature's sweetest gift, has numerous health benefits (Rashid et al., 2013). Stevia is approximately 20 to 30 times sweeter than common table sugar, caloriefree and non-disruptive to blood sugar levels without any side effects. It is also an alternative source to the synthetic sweetening agents like saccharine, aspertame, asulfam-K that are available in the market to the diet conscious consumers and diabetics (Aladakatti et al., 2012). Recently in many countries stevia becomes a popular source of dietary supplement. As Bangladesh is mainly an agro-based country, stevia cultivation has an immense scope for intensive agriculture and precision farming and fits well for high return agriculture (Barathi, 2003). Now it becomes a new avenue to do research for the researcher and is a good opportunity for the farmers to earn cash money through stevia. Incorporation of stevia into agricultural production systems depends upon details information regarding the plant, its agronomic potential and nutritional requirement (Ramesh et al., 2007). Unfortunately no detailed study has yet been conducted on suitability of soil, organic and inorganic fertilizer requirement, pest management, chemical and/or biochemical constituents etc. for large scale cultivation of stevia in Bangladesh. Some preliminary experiments on morphological and physiological parameters have been conducted by BSRI and brac. Few sporadic trials on the growth and leaf yield of stevia have been conducted both at pot and field conditions (Hasan, 2008; Khan, 2014). Recently, suitable soil
(Zaman et al., 2015a), $\mathrm{N}$ and $\mathrm{S}$ requirement, critical $\mathrm{N}$ and $S$ content (Zaman et al., 2016a and 2016b) and $P$ use efficiency and critical P content (Zaman et al., 2017) in stevia grown in both acid and non-calcareous soil has been reported in Bangladesh.

Amendment of organic materials such as crop residues, animal manures, green manures to soils directly affect soil organic matter content, soil fertility, soil physical characteristics, and augmentation of microbial activities, amelioration of metal toxicity (Escobar and Hue, 2008; Roy and Kashem, 2014 and Wong and Swift, 2003). Cow dung has long been recognized as perhaps the most desirable animal manures because of its high nutrient and organic matter content. Addition of cow dung increases the organic carbon content of degraded soil which may lead to the increasing activity of beneficial soil microorganisms as well as the fertility status of soil by increasing the availability of nutrients for the plants from soil. Cow dung significantly increased the growth and yield of plants (Gudugi, 2013; Akande et al., 2006; Mehedi et al., 2011). This study therefore sought to evaluate the effects of cow dung on growth, leaf biomass yield of stevia and its effect on the fertility status of post harvest soil in the ecological condition of Bangladesh Agricultural University.

\section{Materials and Methods}

The experiment was carried out with stevia plant in the Department of Agricultural Chemistry, BAU, Mymensingh during February to May, 2012. The 
research work was accomplished in 24 earthen pots in a completely randomized design with three replications. Two soils (acid and non-calcareous) of contrasting physicochemical properties (Zaman et al., 2015a) collected from Madhupur (Tangail) and BAU campus (Mymensingh), respectively were used. The soil was mixed thoroughly with cow dung (CD) as per treatments @ $\mathrm{CD}_{0}$ (control), $\mathrm{CD}_{5}\left(5 \mathrm{t} \mathrm{ha}^{-1}\right), \mathrm{CD}_{7.5}\left(7.5 \mathrm{t} \mathrm{ha}^{-1}\right)$ and $\mathrm{CD}_{10}\left(10 \mathrm{t} \mathrm{ha}^{-1}\right)$. The CD contained 24.03, 1.05, 0.35, $0.45,0.24,0.16$ and $0.015 \%$ organic C, total $\mathrm{N}, \mathrm{P}, \mathrm{K}, \mathrm{S}$, $\mathrm{Ca}$ and $\mathrm{Mg}$, respectively. Eight $\mathrm{kg}$ of processed soil was taken in each earthen pot. Forty five days old in vitro produced stevia seedlings were collected from BRAC Biotechnology Laboratory, Joydebpur, Gazipur to use in the experiment. For the initial growth and development of the seedling, small amounts of urea were applied to each pot including control. Intercultural operations like irrigation, soil loosening, weeding, plant protection and deflowering were done as and when necessary. Harvesting, cleaning, drying and weighing were done properly. Plant height, number of branches, number of leaves, leaf area, fresh leaf weight and dry leaf weight plant $^{-1}$ were studied at 15 days interval. Initial and postharvest soil properties were determined following standard methods (Page et al., 1982) in the Laboratories of the Departments of Agricultural Chemistry,
Biochemistry, Professor Muhammed Hussain Central Laboratory (PMHCL), BAU, Mymensingh and SRDI Regional Laboratory, Dhaka. Analysis of variance (ANOVA) was done following the principle of Fstatistics and the mean values were separated by Latin Square Design (LSD) (Gomez and Gomez, 1984).

\section{Results and Discussion}

\section{Effect of CD on plant height}

Amendments of organic matter in soil significantly affect plant height. Effects of different CD doses on plant height in both acid and non-calcareous soil is given in Table 1. The application of CD influenced plant height and it was increased with the advanced doses of CD. The shortest plants were recorded with control in both soils. However, the tallest plant $(98 \mathrm{~cm}$ in acid soil and $94 \mathrm{~cm}$ in non-calcareous soil) was found in the pots receiving higher CD dose @ $10 \mathrm{t} \mathrm{ha}^{-1}$. Gudugi (2013) reported similar result in okra and concluded that CD @ $20 \mathrm{t} \mathrm{ha}^{-1}$ was responsible for getting the tallest plant. Height increase was $58 \%$ higher in acid soil and $57 \%$ higher in non-calcareous soil over control. It was observed that the pots subjected to $\mathrm{CD}_{7.5}$ and $\mathrm{CD}_{10}$ were significantly higher than other treatments at 60 DAP.

Table 1. Effects of different levels of cow dung (CD) on the plant height of stevia at various DAP

\begin{tabular}{lcccccccccc}
\hline & \multicolumn{4}{c}{ Acid soil } \\
\cline { 2 - 11 } CD level & \multicolumn{4}{c}{ DAP } & \multicolumn{3}{c}{ D } & \multicolumn{4}{c}{ Non-calcareous soil } \\
\cline { 2 - 11 } & 10 & 15 & 30 & 45 & 60 & 0 & 15 & 30 & 45 & 60 \\
\hline $\mathrm{CD}_{0}$ & $11.0 \mathrm{~b}$ & $16.3 \mathrm{~b}$ & $33.0 \mathrm{c}$ & $49.0 \mathrm{~b}$ & $62.0 \mathrm{c}$ & 13.3 & $19.3 \mathrm{c}$ & $43.0 \mathrm{c}$ & $51.7 \mathrm{~b}$ & $60.0 \mathrm{c}$ \\
$\mathrm{CD}_{5}$ & $12.7 \mathrm{ab}$ & $44.7 \mathrm{~b}$ & $61.3 \mathrm{~b}$ & $77.0 \mathrm{~b}$ & 14.0 & $21.0 \mathrm{bc}$ & $48.0 \mathrm{bc}$ & $58.3 \mathrm{~b}$ & $73.3 \mathrm{bc}$ \\
$\mathrm{CD}_{7.5}$ & $12.7 \mathrm{a}$ & $24.7 \mathrm{a}$ & $53.0 \mathrm{ab}$ & $77.7 \mathrm{a}$ & $87.7 \mathrm{ab}$ & 15.0 & $24.7 \mathrm{ab}$ & $53.0 \mathrm{ab}$ & $77.3 \mathrm{a}$ & $84.3 \mathrm{ab}$ \\
$\mathrm{CD}_{10}$ & $13.0 \mathrm{a}$ & $26.7 \mathrm{a}$ & $60.0 \mathrm{a}$ & $80.3 \mathrm{a}$ & $98.3 \mathrm{a}$ & 15.0 & $27.0 \mathrm{a}$ & $56.7 \mathrm{a}$ & $82.0 \mathrm{a}$ & $93.7 \mathrm{a}$ \\
$\mathrm{CV}(\%)$ & 2.1 & 2.0 & 2.3 & 2.1 & 1.8 & 1.3 & 1.6 & 1.3 & 2.0 & 1.8 \\
$\mathrm{LSD}$ & 2.8 & 3.2 & 4.9 & 7.4 & 8.1 & 2.3 & 2.6 & 4.8 & 6.6 & 8.3 \\
$\mathrm{SE} \pm$ & 0.7 & 1.4 & 3.3 & 4.2 & 4.5 & 0.6 & 1.1 & 1.9 & 4.1 & 4.2 \\
\hline
\end{tabular}

$\mathrm{DAP}=$ Days after planting, $\mathrm{CV}=$ Coefficient of variance, $\mathrm{LSD}=$ Least significant difference, $\mathrm{SE} \pm=$ Standard error of means

\section{Effect of CD on branch number}

It is well established that the addition of organic fertilizers increased the organic matter contents of the soil and availability of other plant nutrients (Brar et al., 2004). For this reason the number of branches plant ${ }^{-1}$ was significantly increased due to the application of different levels of $\mathrm{CD}$ in both acid and non-calcareous soil (Table 2). The result revealed that branches plant ${ }^{-1}$ progressively increased with increasing levels of CD up to $10 \mathrm{t} \mathrm{ha}^{-1}$ in both soils. The highest number of branches plant $^{-1}$ at 60 DAP was counted from the plant receiving $10 \mathrm{t} \mathrm{CD} \mathrm{ha}^{-1}$ which was identical with $\mathrm{CD}_{7.5}$ but significantly different from other treatments. The lowest branch number was counted from control.

Table 2. Effects of different levels of cow dung (CD) on the branch number of stevia at various DAP

\begin{tabular}{|c|c|c|c|c|c|c|c|c|c|c|}
\hline \multirow{3}{*}{ CD level } & \multicolumn{5}{|c|}{ Acid soil } & \multicolumn{5}{|c|}{ Non-calcareous soil } \\
\hline & \multicolumn{5}{|c|}{ DAP } & \multicolumn{5}{|c|}{ DAP } \\
\hline & 0 & 15 & 30 & 45 & 60 & 0 & 15 & 30 & 45 & 60 \\
\hline $\mathrm{CD}_{0}$ & 1.0 & $1.3 \mathrm{~b}$ & $1.7 \mathrm{~b}$ & $1.7 \mathrm{~b}$ & $1.7 \mathrm{~b}$ & 1.0 & $1.3 \mathrm{~b}$ & $1.3 \mathrm{~b}$ & $1.7 \mathrm{c}$ & $1.7 \mathrm{c}$ \\
\hline $\mathrm{CD}_{5}$ & 1.0 & $2.0 \mathrm{a}$ & $2.3 \mathrm{a}$ & $2.3 \mathrm{a}$ & $3.3 \mathrm{a}$ & 1.0 & $2.3 \mathrm{ab}$ & $2.7 \mathrm{ab}$ & $2.7 \mathrm{bc}$ & $3.0 \mathrm{bc}$ \\
\hline $\mathrm{CD}_{7.5}$ & 1.0 & $1.7 \mathrm{a}$ & $2.7 \mathrm{a}$ & $3.0 \mathrm{a}$ & $3.7 \mathrm{a}$ & 1.0 & $3.0 \mathrm{a}$ & $3.7 \mathrm{a}$ & $3.7 \mathrm{ab}$ & $4.0 \mathrm{ab}$ \\
\hline $\mathrm{CD}_{10}$ & 1.0 & $2.3 \mathrm{a}$ & $3.0 \mathrm{a}$ & $3.3 \mathrm{a}$ & $4.0 \mathrm{a}$ & 1.0 & $3.3 \mathrm{a}$ & $4.0 \mathrm{a}$ & $4.3 \mathrm{a}$ & $4.7 \mathrm{a}$ \\
\hline $\mathrm{CV}(\%)$ & 0.0 & 3.8 & 3.6 & 3.4 & 3.4 & 0.0 & 3.9 & 4.3 & 3.9 & 4.0 \\
\hline $\mathrm{LSD}_{0.05}$ & 0.0 & 0.8 & 0.9 & 0.8 & 0.8 & 0.0 & 0.8 & 0.9 & 0.8 & 0.9 \\
\hline $\mathrm{SE} \pm$ & 0.0 & 0.2 & 0.3 & 0.3 & 0.3 & 0.0 & 0.3 & 0.4 & 0.4 & 0.4 \\
\hline
\end{tabular}

$\mathrm{DAP}=$ Days after planting, $\mathrm{CV}=$ Coefficient of variance, $\mathrm{LSD}=$ Least significant difference, $\mathrm{SE} \pm=$ Standard error of means 
The result was analogus to the findings reported by different researchers (Brar et al. 2004; Al- Mustafa et al., 1995 and Singh and Singh 1999). Ailincăi et al. (2010) also reported highest increase in the number of tillers of wheat and different horticultural crops treated with high dose of oilcake and sewage sludge.

\section{Effect of CD on leaf number}

The data pertaining to the number of leaves plant ${ }^{-1}$ as influenced by different levels of CD in both acid and non-calcareous soils at various DAP have been presented in Table 3. Application of CD at different rates showed significant effect on the number of leaves of stevia plants at all growth stages except 0 DAP irrespective of soils and treatments used. Leaf number increase was very slow at the early growth stages $(0-30$ DAP) while it was rapid between 30 and 60 DAP irrespective of CD levels except control.

Table 3. Effects of different levels of cow dung (CD) on the leaf number of stevia at various DAP

\begin{tabular}{|c|c|c|c|c|c|c|c|c|c|c|}
\hline \multirow{3}{*}{ CD level } & \multicolumn{5}{|c|}{ Acid soil } & \multicolumn{5}{|c|}{ Non-calcareous soil } \\
\hline & \multicolumn{5}{|c|}{ DAP } & \multicolumn{5}{|c|}{ DAP } \\
\hline & 0 & 15 & 30 & 45 & 60 & 0 & 15 & 30 & 45 & 60 \\
\hline $\mathrm{CD}_{0}$ & $6.3 b$ & $9.7 \mathrm{~d}$ & $16.0 \mathrm{~d}$ & $24.0 \mathrm{~d}$ & $45.0 \mathrm{c}$ & $5.7 \mathrm{~b}$ & $12.3 \mathrm{c}$ & $22.0 \mathrm{c}$ & $31.3 \mathrm{~d}$ & $48.0 \mathrm{~d}$ \\
\hline $\mathrm{CD}_{5}$ & $8.3 \mathrm{a}$ & $19.0 \mathrm{c}$ & $31.3 \mathrm{c}$ & $57.3 \mathrm{c}$ & $90.0 \mathrm{~b}$ & $8.3 \mathrm{a}$ & $25.0 \mathrm{~b}$ & $39.7 b$ & $64.7 \mathrm{c}$ & $95.0 \mathrm{c}$ \\
\hline $\mathrm{CD}_{7.5}$ & $9.3 \mathrm{a}$ & $25.0 \mathrm{~b}$ & $38.0 \mathrm{~b}$ & $70.0 \mathrm{~b}$ & $100.0 \mathrm{~b}$ & $9.0 \mathrm{a}$ & $36.7 \mathrm{a}$ & $46.0 \mathrm{~b}$ & $99.3 b$ & $125.0 \mathrm{~b}$ \\
\hline $\mathrm{CD}_{10}$ & $9.7 \mathrm{a}$ & $33.0 \mathrm{a}$ & $45.0 \mathrm{a}$ & $88.0 \mathrm{a}$ & $159.0 \mathrm{a}$ & $9.7 \mathrm{a}$ & $40.7 \mathrm{a}$ & $60.0 \mathrm{a}$ & $115.3 \mathrm{a}$ & $170.0 \mathrm{a}$ \\
\hline $\mathrm{CV}(\%)$ & 2.9 & 4.1 & 3.4 & 4.0 & 4.2 & 3.2 & 4.0 & 3.4 & 4.3 & 4.2 \\
\hline $\mathrm{LSD}_{0.05}$ & 2.7 & 2.8 & 3.7 & 6.6 & 11.6 & 2.8 & 3.4 & 4.6 & 8.5 & 12.3 \\
\hline $\mathrm{SE} \pm$ & 0.7 & 2.7 & 3.3 & 7.2 & 12.5 & 0.8 & 3.4 & 4.3 & 10.0 & 13.7 \\
\hline
\end{tabular}

$\mathrm{DAP}=$ Days after planting, $\mathrm{CV}=$ Coefficient of variance, $\mathrm{LSD}=$ Least significant difference, $\mathrm{SE} \pm=$ Standard error of means

The main limiting factor for slower growth at early stage was the nutrient deficiency in the soil as the organic manure had not been fully decomposed. But there was a contrary situation in the later growth stage, the stevia of the organic manure cultivation got sufficient nutrient; so the growth was rapid and number of leaves plant ${ }^{-1}$ was higher. Maximum number of leaves (159.0 in acid soil and 170.0 in non-calcareous soil) at harvest was recorded with $\mathrm{CD}_{10}$ which was significantly higher than all other levels of CD in both soils. At harvest, second highest number of leaves (100.0 and 125.0 in acid and non-calcareous soils, respectively) was recorded with $\mathrm{CD}_{7.5}$ which was identical with $\mathrm{CD}_{5}$ in acid soil but significantly different with others in non-calcareous soil. The minimum number of leaves plant ${ }^{-1}$ was harvested from the plants fertilized with no $\mathrm{CD}$ irrespective of soils and growth period. Wang et al. (2013) also reported similar result i.e. number of leaves plant ${ }^{-1}$ was affected by various levels of CD though CD @ $15 \mathrm{t} \mathrm{ha}^{-1}$ produced maximum number of leaves. Mujahid and Gupta (2010) used oilcake to enhance the leaf structure, number and quality of lettuce. Akdeniz et al. (2006) reported that sewage sludge application $10 \mathrm{t} \mathrm{ha}^{-1}$ positively affected grain yield, leaf number, leaf nitrogen, harvest index, and total $\mathrm{N}$ uptake by sorghum more than other doses.

\section{Effect of CD on leaf area}

Leaf area plant $^{-1}$ responded variably due to the application of different levels of CD (Table 4). There were steady increase in the leaf area of stevia was found with increasing $\mathrm{CD}$ doses. The highest total leaf area plant $^{-1}\left(973 \mathrm{~cm}^{2}\right.$ in acid soil and $1511 \mathrm{~cm}^{2}$ in noncalcareous soil) at harvest was measured from the plant receiving CD@10 t ha ${ }^{-1}$. Second highest values (551 $\mathrm{cm}^{2}$ in acid soil and $969 \mathrm{~cm}^{2}$ in non-calcareous soil) were obtained from $\mathrm{CD}_{7.5}$. Identical leaf area was also obtained from the plants fertilized with $\mathrm{CD}_{7.5}$ and $\mathrm{CD}_{5}$ in non-calcareous soil. Similar type of result was found by Uka et al. (2013) in the cultivation of okra. The lowest leaf area was found from the control treatment irrespective of soils used. $\mathrm{N}$ application at all levels increased leaf area by $109-367 \%$ in acid soil and 154 to $488 \%$ in non-calcareous soil, respectively at harvest.

Table 4. Effects of different levels of cow dung (CD) on leaf area, dry weight and yield increase of stevia leaves over control at harvest

\begin{tabular}{|c|c|c|c|c|c|c|}
\hline \multirow{2}{*}{ CD level } & \multicolumn{2}{|c|}{$\begin{array}{l}\text { Leaf area plant } \\
\qquad\left(\mathrm{cm}^{2}\right)\end{array}$} & \multicolumn{2}{|c|}{$\begin{array}{l}\text { Leaf dry weight } \\
\left(\mathrm{g}_{\text {plant }}^{-1}\right)\end{array}$} & \multirow{2}{*}{$\begin{array}{c}\begin{array}{c}\text { Yield increase } \\
\text { over control }(\%)\end{array} \\
\text { Acid } \\
\text { soil }\end{array}$} & \multirow{2}{*}{$\begin{array}{c}\text { Yield increase } \\
\text { over control }(\%)\end{array}$} \\
\hline & $\begin{array}{c}\text { Acid } \\
\text { soil }\end{array}$ & $\begin{array}{c}\text { Non-calcareous } \\
\text { soil }\end{array}$ & $\begin{array}{c}\text { Acid } \\
\text { soil }\end{array}$ & $\begin{array}{c}\text { Non-calcareous } \\
\text { soil }\end{array}$ & & \\
\hline $\mathrm{CD}_{0}$ & $208 d$ & $257 \mathrm{c}$ & $1.35 \mathrm{c}$ & $1.44 \mathrm{~d}$ & - & - \\
\hline $\mathrm{CD}_{5}$ & $435 c$ & $654 \mathrm{~b}$ & $2.71 \mathrm{~b}$ & $2.85 \mathrm{c}$ & 101 & 98 \\
\hline $\mathrm{CD}_{7.5}$ & $551 \mathrm{~b}$ & $973 b$ & $3.05 \mathrm{~b}$ & $3.90 \mathrm{~b}$ & 126 & 171 \\
\hline $\mathrm{CD}_{10}$ & $973 a$ & $1511 \mathrm{a}$ & $4.97 \mathrm{a}$ & $5.44 \mathrm{a}$ & 268 & 278 \\
\hline $\mathrm{CV}(\%)$ & 4 & 5 & 4.39 & 4.40 & - & - \\
\hline $\mathrm{LSD}_{0.05}$ & 66 & 197 & 0.35 & 0.40 & - & - \\
\hline $\mathrm{SE} \pm$ & 69 & 119 & 0.40 & 0.45 & - & - \\
\hline
\end{tabular}

$\mathrm{CV}=$ Coefficient of variance, $\mathrm{LSD}=$ Least significant difference, $\mathrm{SE} \pm=$ Standard error of means 


\section{Effect of CD on dry weight}

Dry weight progressively increased with increasing levels of CD application up to $10 \mathrm{tha}^{-1}$ in both soils (Table 4). The highest (4.97g in acid soil and $5.44 \mathrm{~g}$ in non-calcareous soil) and the second highest $(3.05 \mathrm{~g}$ in acid soil and $3.90 \mathrm{~g}$ in non-calcareous soil) dry weight plant $^{-1}$ at harvest were measured from the plant receiving maximum level of $\mathrm{CD}_{10}$ and $\mathrm{CD}_{7.5}$, respectively. In acid soil stevia receiving $\mathrm{CD}_{7.5}$ and $\mathrm{CD}_{5}$ doses showed identical result. The lowest values were recorded from the control treatment. $\mathrm{CD}$ application at all levels increased leaf dry yield at harvest by 101 to $268 \%$ in acid soil and 98 to $278 \%$ in non-calcareous soil, respectively over control. Tanimu et al. (2007) confirmed similar result in case of Maize. El-Dewiny et $a l$. (2006) showed that dry weight of radish and spinach plants increased with application of sewage sludge.

\section{Effect of CD on fresh weight}

The fresh weight of stevia leaves plant ${ }^{-1}$ at harvest varied significantly due the application of different levels of CD (Fig. 1). Results revealed that fresh weight progressively increased with increasing levels of $\mathrm{CD}$. The highest fresh weight plant $^{-1}(17.72 \mathrm{~g}$ in acid soil and $18.96 \mathrm{~g}$ in noncalcareous soil) at harvest was measured from the plant receiving $10 \mathrm{t} \mathrm{CD} \mathrm{ha}^{-1}$ which was significantly higher than other levels of $\mathrm{CD}$. The lowest values were obtained from the control treatment $(5.01 \mathrm{~g}$ in acid soil and $5.35 \mathrm{~g}$ in non-calcareous soil). CD application at all levels increased fresh weight at harvest by 5.11 to $12.71 \mathrm{~g}$ plant $^{-1}$ in acid soil and 5.25to 13.61g plant ${ }^{-1}$ in noncalcareous soil.

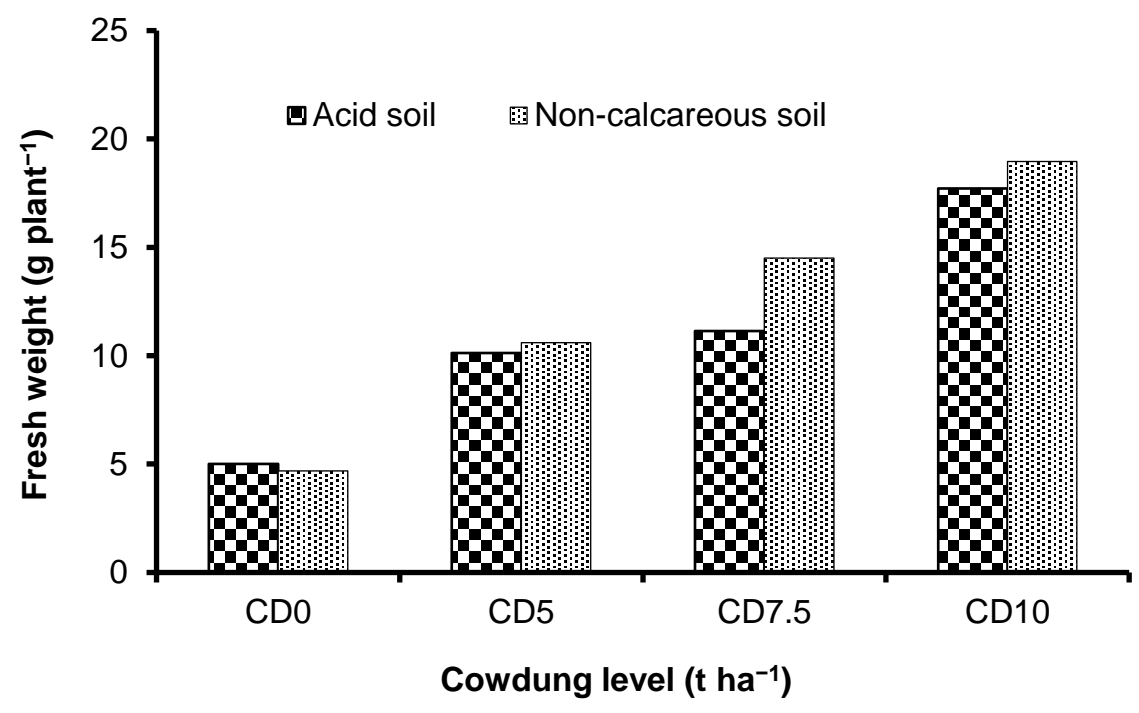

Fig. 1. Effects of different levels of cow dung (CD) on the fresh weight of stevia leaves at harvest

The finding of the present study was homologous as the findings reported by Zaman et al., (2015b) using vermicompost as organic additives. Mehedi et al. (2011) also described highest yield of carrot applying CD @ 15 $\mathrm{t} \mathrm{ha}^{-1}$. El-Dewiny et al. (2006) showed that fresh weight of radish and spinach plants increased with increased application of sewage sludge. The fresh weight of leaves varied with levels and types of organic amendment irrespective of soils used. Similar result was reported by Uka et al. (2013) for the fresh weight of okra.

\section{Effect of CD on post harvest fertility of soil}

The data pertaining to post harvest soil properties as influenced by different levels of CD application have been presented in Table $5 \mathrm{a}$ and $5 \mathrm{~b}$. It can be seen from the Tables that all the parameters were significantly influenced by the addition of CD irrespective of soils used. The values of the soil parameters as expected were increased with the increased levels of CD. The acidity of both soils was reduced to some extent and favors the growth and yield of stevia. At all $\mathrm{CD}$ levels, $\mathrm{pH}$ increased by 0.3 to 0.5 units in both soils. Wang et al. (2013) depicted the same opinion that any organic material if added to the soil that will reduce soil acidity. They reported that addition of the plant residues increased soil $\mathrm{pH}$ by $0.1-0.8 \mathrm{U}$. This might be due to the fact that when organic residues (plant or animal) are added to the soil, they release organic anions which neutralize the hydrogen ion of the acid soil. 
Table 5a. Effects of different levels of cow dung (CD) on the fertility of post harvest soils

\begin{tabular}{lcccccccccc}
\hline $\begin{array}{l}\text { Levels } \\
\text { of CD }\end{array}$ & \multicolumn{2}{c}{$\mathrm{pH}$} & \multicolumn{3}{c}{$\begin{array}{c}\text { Organic matter } \\
(\%)\end{array}$} & \multicolumn{2}{c}{$\begin{array}{c}\text { Total N } \\
\left(\mu \mathrm{g} \mathrm{g}^{-1}\right)\end{array}$} & \multicolumn{2}{c}{$\begin{array}{c}\text { Available P } \\
\left(\mu \mathrm{g} \mathrm{g}^{-1}\right)\end{array}$} & \multicolumn{2}{c}{$\begin{array}{c}\text { Exch. K } \\
\left(\mathrm{Cmol} \mathrm{kg}^{-1}\right)\end{array}$} \\
\cline { 2 - 12 } & $\mathrm{AS}$ & $\mathrm{NS}$ & $\mathrm{AS}$ & $\mathrm{NS}$ & $\mathrm{AS}$ & $\mathrm{NS}$ & $\mathrm{AS}$ & $\mathrm{NS}$ & $\mathrm{AS}$ & $\mathrm{NS}$ \\
\hline $\mathrm{CD}_{0}$ & $4.9 \mathrm{~b}$ & $6.5 \mathrm{c}$ & $1.70 \mathrm{~b}$ & $1.28 \mathrm{~b}$ & $0.10 \mathrm{~b}$ & $0.12 \mathrm{~b}$ & $2.83 \mathrm{c}$ & $10.00 \mathrm{c}$ & $0.18 \mathrm{~b}$ & $0.15 \mathrm{~b}$ \\
$\mathrm{CD}_{5}$ & $5.2 \mathrm{a}$ & $6.8 \mathrm{~b}$ & $1.95 \mathrm{~b}$ & $1.98 \mathrm{a}$ & $0.15 \mathrm{~b}$ & $0.17 \mathrm{~b}$ & $3.90 \mathrm{~b}$ & $13.16 \mathrm{c}$ & $0.21 \mathrm{ab}$ & $0.18 \mathrm{ab}$ \\
$\mathrm{CD}_{7.5}$ & $5.3 \mathrm{a}$ & $7.0 \mathrm{a}$ & $2.26 \mathrm{ab}$ & $2.51 \mathrm{a}$ & $0.18 \mathrm{a}$ & $0.21 \mathrm{a}$ & $4.96 \mathrm{~b}$ & $16.18 \mathrm{~b}$ & $0.25 \mathrm{a}$ & $0.22 \mathrm{a}$ \\
$\mathrm{CD}_{10}$ & $5.4 \mathrm{a}$ & $7.2 \mathrm{a}$ & $2.55 \mathrm{a}$ & $2.96 \mathrm{a}$ & $0.23 \mathrm{a}$ & $0.24 \mathrm{a}$ & $6.00 \mathrm{a}$ & $19.19 \mathrm{a}$ & $0.28 \mathrm{a}$ & $0.25 \mathrm{a}$ \\
$\mathrm{CV}(\%)$ & $3 .($ & 3.1 & 2.52 & 4.29 & 3.59 & 5.30 & 3.92 & 5.42 & 4.62 & 5.10 \\
$\mathrm{LSD}$ & 0.4 & 0.4 & 0.31 & 0.35 & 0.04 & 0.05 & 0.39 & 2.35 & 0.07 & 0.05 \\
$\mathrm{SE} \pm$ & 0.1 & 0.2 & 0.08 & 0.13 & 0.02 & 0.01 & 0.09 & 0.91 & 0.01 & 0.01 \\
\hline
\end{tabular}

$\mathrm{AS}=$ Acid soil, $\mathrm{NS}=$ Non-calcareous soil, $\mathrm{CV}=$ Coefficient of variance, $\mathrm{LSD}=$ Least significant difference, $\mathrm{SE} \pm=$ Standard error of means, Exch.= Exchangeable

Table 5b. Effects of different levels of cow dung (CD) on the fertility of post harvest soils

\begin{tabular}{lcccccccccc}
\hline \multirow{2}{*}{$\begin{array}{l}\text { Levels } \\
\text { of CD }\end{array}$} & \multicolumn{2}{c}{$\begin{array}{c}\text { Available } \mathrm{S} \\
\left(\mu \mathrm{g} \mathrm{g}^{-1}\right)\end{array}$} & \multicolumn{2}{c}{$\begin{array}{c}\text { Exch. Ca } \\
(\mathrm{Cmol} \mathrm{kg})\end{array}$} & \multicolumn{2}{c}{$\begin{array}{c}\text { Exch. Mg } \\
(\mathrm{Cmol} \mathrm{kg})\end{array}$} & \multicolumn{2}{c}{$\begin{array}{c}\text { Available Zn } \\
\left(\mu \mathrm{g} \mathrm{g}^{-1}\right)\end{array}$} & \multicolumn{2}{c}{$\begin{array}{c}\text { Available B } \\
\left(\mu \mathrm{g} \mathrm{g}^{-1}\right)\end{array}$} \\
\cline { 2 - 12 } & $\mathrm{AS}$ & $\mathrm{NS}$ & $\mathrm{AS}$ & $\mathrm{NS}$ & $\mathrm{AS}$ & $\mathrm{NS}$ & $\mathrm{AS}$ & $\mathrm{NS}$ & $\mathrm{AS}$ & $\mathrm{NS}$ \\
\hline $\mathrm{CD}_{0}$ & $13.06 \mathrm{~d}$ & $13.00 \mathrm{~d}$ & $0.15 \mathrm{~b}$ & $2.10 \mathrm{~b}$ & $0.60 \mathrm{~b}$ & $1.20 \mathrm{~b}$ & $1.30 \mathrm{~b}$ & 0.80 & $0.33 \mathrm{~b}$ & $0.23 \mathrm{~b}$ \\
$\mathrm{CD}_{5}$ & $15.10 \mathrm{c}$ & $15.19 \mathrm{c}$ & $1.89 \mathrm{a}$ & $6.95 \mathrm{a}$ & $0.72 \mathrm{~b}$ & $3.39 \mathrm{ab}$ & $1.64 \mathrm{a}$ & 0.84 & $0.36 \mathrm{~b}$ & $0.29 \mathrm{~b}$ \\
$\mathrm{CD}_{7.5}$ & $18.35 \mathrm{~b}$ & $22.87 \mathrm{~b}$ & $2.15 \mathrm{a}$ & $7.20 \mathrm{a}$ & $0.97 \mathrm{~b}$ & $5.59 \mathrm{a}$ & $1.75 \mathrm{a}$ & 0.87 & $0.79 \mathrm{a}$ & $0.36 \mathrm{a}$ \\
$\mathrm{CD}_{10}$ & $22.90 \mathrm{a}$ & $27.95 \mathrm{a}$ & $2.43 \mathrm{a}$ & $8.43 \mathrm{a}$ & $1.84 \mathrm{a}$ & $7.69 \mathrm{a}$ & $1.83 \mathrm{a}$ & 0.94 & $0.92 \mathrm{a}$ & $0.47 \mathrm{a}$ \\
$\mathrm{CV} \%)$ & 4.19 & 11.40 & 12.73 & 5.32 & 4.57 & 8.31 & 5.22 & 5.81 & 10.13 & 5.30 \\
$\mathrm{LSD}$ & 1.60 & 4.21 & 0.35 & 0.86 & 0.13 & 0.56 & 0.64 & 0.32 & 0.20 & 0.07 \\
$\mathrm{SE} \pm$ & 0.53 & 2.39 & 0.42 & 0.53 & 0.06 & 0.52 & 0.10 & 0.09 & 0.07 & 0.05 \\
\hline
\end{tabular}

$\mathrm{AS}=$ Acid soil, $\mathrm{NS}=$ Non-calcareous soil, $\mathrm{CV}=$ Coefficient of variance, LSD = Least significant difference, SE $\pm=$ Standard error of means, Exch.= Exchangeable

The organic matter $(\mathrm{OM})$ content of the post-harvest soils significantly increased due to the application of cow dung in both soils as it contains higher amount of OM than any other organic additives of soil. Organic matter content of the acid soil ranged from 1.70 to $2.55 \%$ where as in the non-calcareous soil it ranged from 1.28 to $2.96 \%$. The contents of total $\mathrm{N}$, available $\mathrm{P}$, exchangeable $\mathrm{K}, \mathrm{Ca}, \mathrm{Mg}$, available $\mathrm{S}, \mathrm{Zn}, \mathrm{B}$ were significantly increased with the increased levels of $\mathrm{CD}$ up to $10 \mathrm{t} \mathrm{ha}^{-1}$ in both soils. All the nutrient contents except available $\mathrm{P}$ content were much higher in noncalcareous soil compared to acid soil. The highest values of the parameters were obtained from $\mathrm{CD}_{10}$ and the lowest from the initial soil $\left(\mathrm{CD}_{0}\right)$.

\section{Conclusion}

The present study revealed that the application of cow dung at different levels positively influenced all the characters studied. Cow dung application have been found to be increased the total $\mathrm{N}$, available $\mathrm{P}$, exchangeable $\mathrm{K}, \mathrm{Ca}, \mathrm{Mg}$, available $\mathrm{S}, \mathrm{Zn}$ and $\mathrm{B}$ contents in soils and biomass yield of stevia over the control significantly with the increased levels of $\mathrm{CD}$ up to its highest level in both soils. The parameters were increased with the advancement of growth period (60 DAP) and increased rate of CD up to $10 \mathrm{tha}^{-1}$. Thus it can be advised that CD @ $10 \mathrm{t} \mathrm{ha}^{-1}$ might be applied to get maximum leaf biomass yield of stevia and for increasing the fertility of both soils.

\section{Acknowledgement}

The authors are grateful to the concerned authority of Bangladesh Agricultural Research Council (BARC), Farmgate, Dhaka for financial support.

\section{References}

Ailincăi, C., Jităreanu, G., Ailincăi, D. and Balan, A. 2010. Influence of some organic residues on wheat and maize yield and eroded soil fertility. Cercetări Agronomice in Moldova, 43: 141 .

Akande, M.O., Oluwatoyinbo, F.I., Kayode, C.O. and Olowokere, F.A. 2006. Response of maize (Zea mays) and okra (Abelmoschus esculentus) intercrop relayed with cowpea (Vigna unguiculata) to different levels of cow dung amended phosphate rock. World J. Agric. Sci., 2: 119.

Akdeniz, H., Yılmaz, I., Bozkurt, M.A. and Keskin, B. 2006. The effects of sewage sludge and nitrogen applications on grain sorghum grown (Sorghum vulgare L.) in Van-Turkey. Pol. J. Environ. Stud., 15: 19-26.

Aladakatti, Y.R., Palled, Y.B., Chetti, M.B., Halikatti, S.I., Alagundagi, S.C., Patil, P.L., Patil, V.C. and Janawade, A.D. 2012. Effect of nitrogen, phosphorus and potassium levels on growth and yield of stevia (Stevia rebaudiana Bertoni). Karnataka J. Agric. Sci.., 25: 25-29.

Al-Mustafa, W.A., El-Shall, A.A., Abdallah, A.E., Modaihsh, A.S. 1995. Response of wheat to sewage sludge applied under two different moisture regimes. Exp. Agric., 31: 35-59.

Barathi, N. 2003. Stevia- The calorie free natural sweetener. Natural Prod. Radi.., 2: 20-122.

Brar, B.S., Singh, M.V., Dhillon, N.S. and Benipal, D.S. 2004. Soil quality, crop productivity and sustainable experiences under long-term maize-wheat-cowpea cropping. In: Inceptisols Research Bulletin. Ludhiana, Punjab: Department of Soil, Punjab Agricultural University 1-90. 
El-Dewiny, C.Y., Moursy, K.S. and El-Aila, H.I. 2006. Effect of organic matter on the release and availability of phosphorus and their effects on spinach and radish plants. Res. J. Agric. Biol. Sci., 2: 103-108.

Gomez, K.A. and Gomez, A.A. 1984. Statistical Procedure for Agricultural Research. $2^{\text {nd }}$ edn. International Rice Research Institute. Los Banos, Philippines. pp. 207-215.

Gudugi, I.A.S. 2013. Effect of cowdung and variety on the growth and yield of okra (Abelmoschus esculentus L.). Eur. J. Exp. Biol., 3: 495-498.

Hasan, H.M. 2008. Agronomic management practice for the improvement of growth and yield of stevia (Stevia rebaudiana Bert.). MS Thesis, Department of Agronomy, Bangladesh Agricultural University, Mymensingh.

Khan, M.A.R. 2014. Production technology of stevia (stevia rebaudiana) by stem cutting. PhD Thesis, Department of Agronomy, Bangladesh Agricultural University, Mymensingh

Mehedi, T.A., Siddique, M.A. and Shahid, S.B. 2012. Effect of urea and cow dung on growth and yield of carrot. J. Bangladesh Agril. Univ., 10: 9-13.

Mujahid, A.M. and Gupta, A.J. 2010. Effect of plant spacing, organic manures and inorganic fertilizers and their combinations on growth, yield and quality of lettuce (Lactuca sativa). Indian J. Agric. Sci.. 80: 177-181.

Page, A.L., Miller, R.H. and Keeney, D.R. (eds). 1982. Method of Soil Analysis, Part-2 Chemical and Microbiological Properties, $2^{\text {nd }}$ edn., American Society of Agronomy, Inc. Madison, Wisconsin, USA

Ramesh, K., Singh, V. and Ahuja, P.S. 2007. Production potential of Stevia rebaudiana (Bert.) Bertoni under intercropping systems. Arch Agron Soil Sci., 53: 443-58.

Rashid, Z., Rashid, M., Inamullah, S., Rasool, S. and Bahar, F.A 2013. Effect of different levels of farmyard manure and nitrogen on the yield and nitrogen uptake by stevia (Stevia rebaudiana Bertoni). African J. Agric. Res., 8: 3941-3945.

Singh, C.P.J. and Singh, S.S. 1999. Effect of urea and sludge based compost application on the yield of wheat (Triticum aestivum L.). Madras Agric. J., 86: 511-513.
Tanimu, J., Uyovbisere, E.O., Lyocks, S.W.J. and Tanimu, Y. 2007. Effects of Cow Dung on the Growth and Development of Maize Crop. Greener J. Agric. Sci., 3(5): 371-383,

Uka, U.N., Chukwuka, K.S. and Iwuagwu, M. 2013. Relative effect of organic and inorganic fertilizers on the growth of okra (Abelmoschus esculentus L.) Moeuch. J Agric. Sci.,58: 159-166.

Wang, Y., Tang, C., Wu, J., Liu, X. and Xu, J. 2013. Impact of organic matter addition on $\mathrm{pH}$ change of paddy soil. J. Soil Sediment, 13: 12-13.

Zaman, M.M. 2015. Nutrient requirement leaf yield and stevioside content of stevia (Stevia rebaudiana Bertoni) in some soil types of Bangladesh. PhD Thesis, Department of Agricultural Chemistry, Bangladesh Agricultural University, Mymensingh.

Zaman, M.M., Chowdhury, M.A.H. and Chowdhury, T. 2015a. Growth parameters and leaf biomass yield of stevia (Stevia rebaudiana, Bertoni) as influenced by different soil types of Bangladesh. J. Bangladesh Agril. Univ., 13(1): 33-40.

Zaman, M.M., Chowdhury, M.A.H., Islam, M.R. and Uddin, M.R 2015b. Effects of vermicompost on growth and leaf biomass yield of stevia and post-harvest fertility status of soil. J. Bangladesh Agril. Univ. 13(2): 169-174.

Zaman, M.M., Chowdhury, M.A.H., Mohiuddin, K.M. and Chowdhury, T. 2016a. Nitrogen requirement and critical $\mathrm{N}$ content of stevia grown in two contrasting soils of Bangladesh. Res. Agric. Livest. Fish., 3: 87-97.

Zaman, M.M., Chowdhury, M.A.H., Chowdhury, T. and Hasan, A.B.M.M. 2016b. Critical leaf S concentration and S requirement of stevia grown in two different soils of Bangladesh. Fundam. Appl. Agric., 1(3): 106-111.

Zaman, M., Chowdhury, T., Rahman, M.A. and Chowdhury, M.A.H. 2017. Phosphorus use efficiency and critical $P$ content of stevia grown in acid and non-calcareous soils of Bangladesh. Res. Agric. Livest., Fish., 4 (2): 55-68. 